\title{
Hyperprolactinaemia - a problem in patients from the reproductive period to the menopause
}

\author{
Sylwia Pałubska ${ }^{1}$, Aneta Adamiak-Godlewska², Izabela Winkler ${ }^{3}$, Katarzyna Romanek-Piva ${ }^{4}$, \\ Tomasz Rechberger², Marek Gogacz ${ }^{2}$ \\ ${ }^{1}$ Voivodeship Specialistic Hospital, Lublin, Poland \\ ${ }^{2} 2^{\text {nd }}$ Department of Gynecology, Lublin Medical University, Lublin, Poland \\ ${ }^{3} 2^{\text {nd }}$ Department of Gynecological Oncology, Oncology Centre of the Lublin, Poland \\ ${ }^{4} 2$ nd Chair and Department of Gynecology, Lublin Medical University, Lublin, Poland
}

\begin{abstract}
Hyperprolactinaemia especially affects women in reproductive age $(90 / 100,000)$ but also often is diagnosed in menopause age and leads to disturbances in functioning of $\mathrm{LH}-\mathrm{RH}$ neurons and, as a consequence, to a decrease of FSH and LH, which causes inhibition of oestradiol production. Prolactin is a peptide hormone, phylogenetically one of the oldest, stimulating cells of various organs, which is produced and secreted mainly by lactotrophic acidophilic cells of the anterior lobe of the pituitary. It influences the increase in the mass of the mammary glands, and stimulation and maintenance of lactation after delivery. There are a number of factors apart of pregnancy, delivery, and lactation than can influence secretion of the hormone in other physiological and pathological circumstances, like high-protein diet, stress, REM sleep, or neoplastic tumours, inflammatory diseases, chronic systematic diseases, thyroid hormonal changes, and drug intake. The purpose of this review is to summarise the current knowledge regarding the proper diagnosis and possible influence of hyperprolactinaemia on fertility and menopause symptoms and current treatment methods
\end{abstract}

Key words: hyperprolactinemia, menopause, prolactin.

\section{Introduction}

Prolactin (PRL) is a peptide hormone produced and secreted mainly by lactotrophic acidophilic cells of the anterior lobe of the pituitary. It can also be secreted by the endometrium, placenta, mammary glands, cells of the reticuloendothelial system, and occasionally by neoplastic cells. As for its chemical structure, prolactin is a protein with molecular mass of $23.4 \mathrm{kDa}$, consisting of 199 amino acids, containing three bisulphide bonds $[1,2]$. It is phylogenetically the oldest hormone of the pituitary, which means that it stimulates cells of various organs [3]. The basic function of prolactin is its action on mammary glands. It influences the increase in the mass of the glands, and stimulation and maintenance of lactation after delivery. Thus it exhibits mammotrophic, lactogenic, and galactopoietic action [3]. Prolactin is responsible for the origin of the maternal instinct [4], and it plays a role in immune tolerance during pregnancy. In low (physiological) concentrations it shows a "luteotrophic" effect, acting like gonadotrophin, and in high concentrations it inhibits secretion of the pituitary gonadotrophins.

\section{Causes of increased prolactin blood concentration}

There are a number of factors that affect secretion of the hormone. They include physiological causes as well as those with a pathological basis. The natural causes are e.g. the circadian rhythm or changes in concentrations of other hormones. The concentration of prolactin increases during REM sleep [5]. The highest concentration of the hormone is noted between 2:00 a.m. and 5:00 a.m. [6]. The highest secretion of prolactin is registered in pregnancy, labour, and puerperium - during lactation. An increase in the level of concentration of this hormone is also related to high-protein diet, stress, physical exertion, hypoglycaemia, or sexual intercourse $[3,7]$. There are many substances that raise the concentration of prolactin. They include: a vasoactive intestinal peptide, dopamine, serotonin [3], epithelial growth factor, oxytocin, oestrogens, and histidine [8]. Blood PRL concentrations are also influenced by the hormones of the thyroid gland. In hypothyroidism, concentrations of both thyrotropin (TSH) and prolactin are increased [3]. 
Apart from physiological factors, there are also pathological factors that lead to hyperprolactinaemia. They include diseases causing damage to the pituitary cells or other structures of the central nervous system. The group comprises of: neoplastic tumours (craniopharyngioma, meningioma, adenomas, Rathke's pocket cyst), inflammatory conditions (lymphocytic inflammation of the pituitary), operations, injuries, radiation of the pituitary or the hypothalamic infundibulum [3], histiocytosis X, temporal arteries inflammation, cerebrospinal meningitis [9], acromegaly, septicaemia, chronic uraemia, or idiopathic factors. An increase in blood lactotropin secretion is also caused by systemic diseases: chronic renal failure, hepatic cirrhosis, epilepsy, injuries and operations of the chest, polycystic ovary syndrome, pseudopregnancy [3], Cushing's disease, and Addison's disease [10].

It is estimated that hyperprolactinaemia mostly affects women aged 25-34 years. The prevalence is 10$90 / 100,000$ people. It also occurs in men but four times less frequently $[11,12]$.

latrogenic hyperprolactinaemia may be caused by improper or long-term administration of cholinergic receptor agonists, dopaminergic receptor blockers, oestrogens, oral contraceptives containing oestrogens, dopamine synthesis inhibitors, anti-hypertensive drugs, antidepressants, antihistamines, antipsychotics, antiemetics (metoclopramide), anaesthetics, drugs inhibiting the action of catecholamines, neuroleptics, neuropeptides, opioids, and their antagonists [3, 13].

\section{Influence of hyperprolactinaemia on the female reproductive system}

Increased blood serum concentration of prolactin causes many disturbances in the function of the gonads. It leads to an imbalance in $\mathrm{GnRH}$ and $\mathrm{LH}$ secretion and, consequently, to hypoestrogenism. Thus it indirectly causes an imbalance in lipid metabolism, osteoporosis, atrophic changes in the genitourinary system, an increase in ACTH and adrenal androgens secretion, disturbances in the pancreatic functions of insulin secretion, and a decrease in sex hormone binding globulin synthesis in the liver [14]. The increased level of androgens impairs in turn development of the oocyte [15].

Hyperprolactinaemia also leads to disturbances in functioning of $\mathrm{LH}-\mathrm{RH}$ neurons and, as a consequence, to a decrease in gonadotrophin secretion (FSH and $\mathrm{LH}$ ), which causes inhibition of oestradiol production. A decrease in blood FSH concentration impairs Graafian follicle maturation, thus leading to anovulatory cycles. Impairment of $\mathrm{LH}$ secretion causes lutein insufficiency [3, $6,10,16]$ through a selective change in the activity of enzymes taking part in steroidogenesis [3]. High prolactin concentrations, even nocturnal increases, lead to inhibition of granulosa cell steroidogenesis, and thus high androgen concentrations are observed during the oocyte development [9, 17-19]. It has been proven, both in functional studies and in vitro cultures [19], that women with nocturnal hyperprolactinaemia are more frequently affected by lutein insufficiency and lowered concentration of oestradiol produced by granulosa cells. This concerns gonadotrophin-stimulated cycles as well as natural cycles $[17,18]$. In vitro studies have revealed that prolactin affects granulosa cells, causing inhibition of oestradiol production [19]. High blood PRL concentrations (above $100 \mathrm{ng} / \mathrm{ml}$ ) lead to destruction of nearly $100 \%$ of ovarian follicles, which, as a consequence, leads to premature extinction of ovarian activity [20]. A decrease in oestrogen concentration caused by hyperprolactinaemia also affects women's sexual life. The most commonly observed symptoms include lowered libido, dryness of the vagina - with subsequent dyspareunia [6], and disturbances in the arousal phase and orgasm [21].

The above action of the PRL hormone is reflected in the clinical manifestation. The most common symptoms include: menstrual disturbances (irregular cycles every six weeks and up to six months, amenorrhoea, oligomenorrhoea, hypomenorrhoea, hypermenorrhoea), shortened menstrual cycles (polymenorrhoea), premature regression of the corpus luteum, premenstrual syndrome, anovulation, lowered libido, dyspareunia, galactorrhoea, hirsutism, acne, headaches, and vision disturbances (with the presence of prolactinoma, mostly macroprolactinoma - (tumour diameter above $1 \mathrm{~cm}$ ) [14]. All the above-mentioned disturbances related to the reproductive system clearly show that hyperprolactinaemia leads to infertility [14].

\section{Diagnostics of hyperprolactinaemia}

Hyperprolactinaemia is not usually a disease in itself. It is only a symptom that makes us suspect disturbances in functions of other organs. Treatment of hyperprolactinaemia and, indirectly, of infertility should begin with thorough diagnostics of the causes of the condition. Diagnosis and treatment of hyperprolactinaemia starts with taking a history and performing a physical examination of the patient. The history should determine whether we are dealing with primary or secondary amenorrhoea. If the patient suffers from secondary amenorrhoea, she describes her menstrual cycles (their duration, regularity). It should be determined while taking the history what drugs the patient takes (whether they influence PRL secretion). The woman should be asked about libido and galactorrhoea (if it occurs in both breasts, spontaneously, or upon stimulation of the nipple). It should be determined whether she has anovulatory cycles and corpus luteum insufficiency. Apart from a gynaecological examination, a physical examination of the patient should be conducted. The doctor should assess the condition of the patient's mammary glands (possible galactorrhoea), the skin (presence of acne changes, hair growth - with high PRL concentrations the 
adrenals can produce excessive amounts of androgens). Pregnancy should be excluded [22].

In order to diagnose the disease a blood sample is collected from the patient's basilic vein or another easily accessible place. It is best to perform the examination in the morning (although not too early because there is a possibility of maintaining high concentrations after the night's rest) $[3,23,24]$. The optimal time is 2-3 hours after waking up. The blood concentration of prolactin during the whole menstrual cycle oscillates within a similar range, and it can slightly increase at ovulation [3].

Hyperprolactinaemia is diagnosed when blood prolactin concentration rises above $25 \mathrm{ng} / \mathrm{ml}$ [3]. We can prove hyperprolactinaemia when at least two test results of blood prolactin concentration are abnormal or a single incidental measurement exceeds the upper limit of the norm at least five times [25].

The norm for prolactin concentration in women of reproductive age ranges between 3 and $25 \mathrm{ng} / \mathrm{ml}$. On average it is $8 \mathrm{ng} / \mathrm{ml}$ [26]. In pregnant women it rises approximately 10 times, and it can even reach $300 \mathrm{ng} / \mathrm{ml}$; in breastfeeding mothers it is $50 \mathrm{ng} / \mathrm{ml}$ on average [3, 26].

The action of metoclopramide, a dopamine receptor antagonist, is used, among others, in diagnostics of hyperprolactinaemia. It is not used for standard tests but rather in diagnostics of the causes of hyperprolactinaemia [3]. Ten milligrams of metoclopramide is administered and PRL blood concentration is checked. Two samples are evaluated: after 60 minutes and after 120 minutes from the drug administration. The normal result of the test after administration of the drug is a 4-6-fold increase in PRL after 60 minutes [6, 10]. An increase greater than six times means functional hyperprolactinaemia. An increase in PRL smaller than two times requires further diagnostics to assess hormonal function of the pituitary and to evaluate the field of vision, and it points to the need to perform magnetic resonance imaging of the sella turcica area [3]. Prolactin concentration above $100 \mathrm{ng} / \mathrm{ml}$ should make us suspect hypophyseal adenoma [26].

Several biological forms of prolactin are known: little form, big form (b-PRL), big-big form (bb-PRL, macroprolactin), and glycoside and phosphorised form [2]. The first one with molecular mass of approximately 23.4 $\mathrm{kDa}$ is the most active form of PRL. The big form comprises secondary and tertiary structures, connected with each other, and has a molecular mass of approximately $50 \mathrm{kDa}$. Macroprolactin $(60-100 \mathrm{kDa})$ is a polymer and is not characterised by high biological activity. The last of the structures - glycoside - has a molecular mass similar to the little form, $25 \mathrm{kDa}$, but it has lower biological activity $[13,27]$. Creation of such structural forms of the PRL hormone is possible thanks to alternative splicing and processes of protein modification af- ter translation: proteolysis, glycolysis, phosphorylation, deamination, demineralisation, polymerisation, and the addition of new molecules [2].

It should also be taken into account in diagnostics of hyperprolactinaemia, that the presence of macroprolactin (big or big-big PRL) in blood serum makes the results of PRL concentration false (it constitutes about $50 \%$ of secreted prolactin) during standard diagnostics [3]. Macroprolactin is a combination of prolactin and immunoglobulin G with molecular mass above $150 \mathrm{kDa}$, characterised by weaker affinity to the receptor (and to biological activity) while maintaining immunoreactivity [28-30]. In this group of patients hyperprolactinaemia may have an asymptomatic course. Additional tests should be done in order to separate individual fractions of prolactin (PRL, big-PRL, and big-big PRL) from each other. This can be achieved by adding $25 \%$ polyethylene glycol solution to the patient's serum and reading the degree of prolactin recovery (precipitation of high-molecular serum proteins) or with the method of filtration on gel [3]. Complex forms of prolactin undergo precipitation. A result $>60 \%$ means prevalence of prolactin monomers in blood serum, and $<40 \%$ indicates prevalence of macroprolactin molecules [31].

It is estimated that macroprolactin is responsible for approximately $10-26 \%$ of cases of elevated blood PRL level $[29,30]$. It should be emphasised that in certain cases hyperprolactinaemia and macroprolactinaemia can be simultaneously diagnosed in the same patient [2].

A blood PRL concentration test should be one of the basic examinations ordered for a patient having problems with conception [3]. Functional hyperprolactinemia is classified as group $\mathrm{VI}$ of infertility and menstruation disturbances division according to $\mathrm{WHO}$ [32]. According to some authors it is responsible for $25 \%$ of cases of secondary amenorrhoea [10]. Hyperprolactinaemia is the cause of $3 \%$ of primary amenorrhoea and $18 \%$ of secondary amenorrhoea in women [33]. As for the causes of secondary amenorrhoea, the elevated level of lactotrophin comes second after disturbances on the hypothalamus-pituitary axis (61\%). Actually, hyperprolactinaemia could also be treated as belonging to this group [33].

\section{Treatment of hyperprolactinaemia}

Treatment of prolactin secretion disturbances depends on the severity of clinical symptoms, a woman's willingness to have offspring, and the presence of the pituitary tumour concomitant with increased prolactin concentration. It should be stressed that functional hyperprolactinaemia does not require treatment unless the patient plans to have offspring or reports troublesome symptoms. If the elevated PRL level is caused by drugs, they should be withdrawn if possible. If it is not possible, diagnostics should also include an MRI of the CNS in order to exclude a tumour of the pituitary [3]. 
It should be remembered that in chronic renal insufficiency the elevated level of the lactotrophic hormone is caused by impairment of its decomposition, and it results from changes in central regulation of its secretion, a decrease in the renal clearance rate, and an increase in its production. Dialysis does not normalise PRL concentration. Kidney transplantation is the treatment option that remains [3]. In this group of women restoration of menstruation can be obtained by including dopamine agonist preparations in the therapy. It is the first-line treatment.

In the course of hyperprolactinaemia resulting from hypothyroidism, one should remember about adjusting L-thyroxine doses. Too low doses administered for a long time may cause hypertrophy of the pituitary and thus make us suspect a tumour. Appropriate treatment of hypothyroidism not only enables us to achieve thyreostasis but also normalisation of prolactin concentration [3].

In a diagnosed tumour of the pituitary, administration of dopamine agonists (bromocriptine, quinagolide, cabergoline) not only causes normalisation of prolactin concentration but also reduction in the size of a tumour and restoration of the reproductive system functions [3]. Inhibition of PRL secretion restores ovulation [34]. The cheapest and most commonly used drug is bromocriptine. It is a bromine derivative of $\alpha$-ergocryptine present in ergot (an endospore of the parasitic Claviceps purpurea fungus from the tubercle family attacking crops, e.g. rye, barley, wheat, and rice). It has a broad spectrum of use. It is administered in the case of pathological lactation and in order to stop physiological lactation, in hyperprolactinaemia without galactorrhoea, and even in treatment of infertility - at normal prolactin concentrations in women who do not ovulate [3]. It is also administered to women with the corpus luteum insufficiency. Such treatment should be continued to the moment of conception. The use of bromocriptine and control of the pituitary PRL reserve pool lead to improved results in infertility treatment [35] through an increase in preovulatory oestradiol blood concentration [36]. The use of bromocriptine in pulsatile doses is also effective in infertility treatment: oral administration between the $5^{\text {th }}$ and $13^{\text {th }}$ day of the menstrual cycle. It is also given in the second phase of the cycle to relieve premenstrual tension (1.25-2.5 mg p.o./24 hours). In standard therapy bromocriptine is used orally in the doses 2.5-12.5 mg daily in the form of tablets [3]. The effect of the drug action after administration p.o. is obtained after two hours and maintained for approximately 10-12 hours. In the treatment of postpartum lactation inhibition, with daily administration of two times, the total effect can be achieved after 2-3 weeks of therapy $[37,38]$.
Bromocriptine can cause side effects in the form of orthostatic decreases in arterial blood pressure, digestive disorders, or drowsiness [3]. It is recommended to take the drug during a meal to avoid possible side effects such as abdominal pain, constipation, nausea, and vomiting or even vertigo and syncope. Undesirable effects occur more frequently at the beginning of the therapy [39]. Occasionally patients do not tolerate bromocriptine and some are even resistant to the drug. The route of administration can then be changed to vaginal $[40,41]$, or a different preparation can be introduced - quinagolide or cabergoline [3]. The last of the preparations mentioned above is recommended by the Endocrine Society in the USA due to its optimum efficacy in restoring the normal PRL level and reducing the pituitary tumour [3]. The therapeutic dose of cabergoline is $0.125-2 \mathrm{mg}$ taken once a week. If there is a need, the dose can be increased from $3 \mathrm{mg}$ to as much as $11 \mathrm{mg}$ per week [3]. Cabergoline causes fewer side effects in comparison with bromocriptine, but it is not so commonly used due to its price [42]. Quinagolide is well tolerated by approximately $95 \%$ of patients and it can be used for even longer than 12 months [43]. It should be emphasised that this selective agonist of D2 receptors lowers the PRL level in approximately 50\% of patients who were resistant to bromocriptine. The therapy is started with a dose of $25 \mu \mathrm{g}$ for the first three days. After three days the dose is increased to $50 \mu \mathrm{g}$ and for the subsequent three days of administration it is raised to $75 \mu \mathrm{g}$ or more. The drug is taken once a day in the evening. The maximum daily dose is $300 \mu \mathrm{g}$ [6].

In $90 \%$ of all treated cases of functional hyperprolactinaemia the optimal PRL level and normalisation of the gonadal function can be achieved [34], in idiopathic functional hyperprolactinaemia the symptoms return after withdrawal of the drugs, and the PRL level increases again. If there is a lack of response to the therapy with dopaminergic receptor agonists in the treatment of infertility caused by hyperprolactinaemia, introduction of clomiphene citrate or gonadotrophins is recommended. The combination of clomiphene with bromocriptine is recommended in infertility related to ovulation disturbances, functional hyperprolactinaemia, and menstruation disturbances [10]. Administration of gonadoliberin should also be considered in this group of women [44]. In patients who, as well as hyperprolactinaemia, are diagnosed with the polycystic ovary syndrome administration of dopamine receptor agonists is recommended as an adjuvant therapy. The drugs should not be given to patients who ovulate normally and whose PRL concentration oscillates within the norm or on a slightly elevated level [42]. In women planning pregnancy, whose prolactin concentration level is increased due to the pituitary tumour - macroprolactinoma, pharmacotherapy is recommended in order to reduce the size of the tumour [34] until the compression symptoms subside. 
In pregnant women with hypophyseal adenoma, aggravation of symptoms and hyperplasia of the tumour are observed due to the action of oestrogens. It concerns macroprolactinoma [2]. In the case of microprolactinoma [34] an increase in the size of the tumour has not been observed. If the foetus is sufficiently mature to survive outside the mother's organism, preterm termination of pregnancy is recommended and pharmacological therapy should be continued in puerperium. In early pregnancy, with concomitant neurological symptoms, treatment with bromocriptine or lisuride (ergot alkaloid) should be introduced. Bromocriptine is not teratogenic and it does not affect development of the foetus. It has the action of maintaining early pregnancies. Opposite opinions can also be found in the literature; according to the reports of Rjosk and von Werder, bromocriptine has little effect in pregnant women. Surgery is recommended in patients in whom pharmacotherapy is ineffective. In early pregnancy, when there is no reaction to pharmacological treatment, termination of pregnancy is recommended [37, 38].

The patient should be monitored during treatment. Measurement of blood PRL concentration is recommended at monthly intervals. The treatment with dopamine agonists is continued until the hormone concentration is normalised and menstruation is restored [3]. When the patient has hypophyseal adenoma, the size of the tumour is checked by MRI examination once a year. When prolactin-secreting macroadenomas are present, MRI can be performed as often as every three months. Another indication to perform MRI examination more frequently is an increase in PRL concentration despite treatment and the onset of other additional symptoms such as galactorrhoea or vision disturbances [3]. The examinations necessary to be performed in women suffering from hypophyseal adenoma include an ophthalmic examination with the visual field assessment and bone density examination to check disturbances caused by hypogonadism. In patients who achieve normalisation of PRL concentration in the blood and whose symptoms subside, the treatment can be discontinued. Patients with microadenoma of the pituitary do not have to be treated after the menopause. Women with a hypophyseal tumour resistant to pharmacological therapy should be treated with the highest doses. When pharmacotherapy fails, the option that remains is a neurosurgical procedure [3]. Tumours (especially macroadenomas) treated surgically show a tendency to relapse in $25-50 \%$ of cases. If surgical treatment does not cause the desired effects, radiotherapy as a complementary treatment is the next step recommended in patients who plan to become pregnant. It should be mentioned that chemotherapy is of little effect in treatment of malignant tumours of the pituitary [3].

Cases with diagnosed idiopathic infertility are also worth mentioning. Several incidental PRL measure- ments can be within the normal range or PRL values can be slightly elevated but oscillate within the norm. However, regular determinations of blood serum PRL concentration indicate increased PRL concentration for several consecutive days at the beginning of the menstrual cycle $\left(1^{\text {st }}-3^{\text {rd }}\right.$ day of the cycle). This can be caused by high concentration of oestradiol at the beginning of the cycle. It has been proven that in such patients administration of bromocriptine for consecutive cycles (from one to four) can lead to pregnancy [45]. This makes us suspect that hyperprolactinaemia, even transient, negatively affects other factors leading to conception and development of pregnancy: fertilisation, implantation, embryogenesis, and the function of the gestational corpus luteum [9]. Nowadays, when approximately $10-15 \%$ of couples are affected by infertility, special attention should be paid to hormonal disturbances, among them - frequently occurring hyperprolactinaemia. Diagnostics of hyperprolactinaemia should be introduced even in the first stages of infertility diagnostics. In light of all this information, close cooperation of a gynaecologist and endocrinologist, sometimes even a neurosurgeon, seems to be crucial.

\section{Hyperprolactinaemia during the menopause}

There is evidence that hyperprolactinaemia mostly affects young women in reproductive age. The incidence of the condition decreases with age. This is caused by a reduction in oestrogen concentration and thus inhibition of lactotrophic cell stimulation. A lack of specific symptoms that characterise the course of the disease means that hyperprolactinaemia is not so commonly diagnosed among menopausal women. The blood PRL level is also spontaneously decreased in this group of women [46, 47]. Karunakaren S. et al. (2011) conducted research on a group of patients with hyperprolactinaemia: pregnant women, menopausal women, and men. They showed that the PRL level in the group of women after the menopause is normalised more often than in the remaining studied groups.

Hyperprolactinaemia caused by hypophyseal adenoma is mostly noted in women between 20 and 40 years of age, and not in menopausal women [48, 49]. There are cases, however, that in patients using HRT adenomas increase their size [50]. Studies by Shimon et al. (2014), in turn, revealed that the pituitary tumours in menopausal women have larger dimensions and are more invasive, in opposition to microadenomas diagnosed in younger patients. Hypophyseal adenomas also cause a significant increase in PRL values in the organism [47].

In patients during the menopause hyperprolactinaemia is manifested not only by the symptoms from the reproductive system [51-53]. Patients suffer from obesi- 
ty, impaired lipid metabolism, or even insulin resistance (it concerns even slim patients) [54]. Another problem is the influence of the increased prolactin level on bone mineralisation and osteoblast proliferation [55, 56]. Bone injuries, fractures, are more common in menopausal women with high PRL concentration caused by hypophyseal adenoma [57]. It has been found that the elevated level of prolactin in menopausal women is related to decreased bone metabolism and osteoarthrosis [58]. Direct PRL action on osteocytes may be one of the causes [59]; another is a decreased oestrogen level caused by the action of prolactin [60] - it is confirmed by examinations of older patients whose treatment included dopaminergic agonists. It has been proven that treatment of hyperprolactinaemia in menopausal women improves their bone mineral density (BMD) $[61,62]$. The results of the studies were confirmed in the group of men with hyperprolactinaemia $[63,64]$. It was noticed that the patients who received dopaminergic agonist drugs obtained an increase in BMD. Thus it is suggested that in examined menopausal women with hyperprolactinaemia bromocriptine should be included in the treatment as a means of prophylaxis $[58,65]$. Cabergoline also exerts a beneficial effect in therapy of hyperprolactinaemia $[66,67]$. Such treatment improves insulin sensitivity of cells and the lipid profile, it decreases BMI and abdominal obesity (all the symptoms caused by high PRL concentrations) [68-70]. Treatment of women after the menopause is similar to treatment of young women - dopamine agonists are first-line drugs in hyperprolactinaemia therapy. The most frequently used bromocriptine causes a decrease in the size of the tumour as well as in the number of lactotrophic cells of the pituitary [63]. Such treatment brings good effects in both young and older patients. Other studies, in turn, suggest that when there are no symptoms of the disease in older patients with microand macroadenomas, MRI examinations should be performed in order to assess the size of the tumour and its possible growth [71]. When characteristic symptoms of hyperprolactinaemia do not occur in menopausal women and the mass of the tumour is relatively small, giving no symptoms, treatment does not need to be introduced, but the patient should be monitored long term with MRI examinations [47].

\section{Acknowledgements}

We thank Professor Krzysztof Postawski for comments that greatly improved the manuscript.

\section{Disclosure}

Authors report no conflict of interest.

\section{References}

1. Freeman ME, Kanyicska B, Lerant A, Nagy G. Prolactin: structure, function and regulation of secretion. Physiol Rev 2000; 80: 1523-1631.

2. Lewandowski KC, Gąsior-Perczak D. Makroprolaktynemia jako problem w praktyce klinicznej. Nowa Klin 2012; 19: 442-444.

3. Skałba P. Diagnostyka i leczenie zaburzeń endokrynologicznych w ginekologii. Medycyna Praktyczna, Kraków 2014; 166-182.

4. Tkaczuk-Włach J, Sobstyl M, Chołubek-Robak D, Jakiel G. Hiperprolaktynemia. Przegl Menopauz 2009; 2: 112-115.

5. Parker DC, Rossman LG, Vanderlaan EF. Relation of sleep-entrained human release to REM-nonREM cycles. J Clin Endocrinol Metab 1974; 38: 646-651.

6. Niedziela P, Dębski R. Hiperprolaktynemia dla seksuologów, Przegl Seksuol 2006; 5: 5-12.

7. Karasek M, Pawlikowski M. Hyperprolactinemia - the Essentials. European Endocrinology 2006; 1: 53-57.

8. Van Klompenberg MK, Manjarin R, Donovan CE, et at. Regulation and localization of vascular endothelial growth factor within the mammary glands during the transition from late gestation to lactation. Domest Anim Endocrinol 2016; 54: 37-47.

9. Krzeska D, Skórka B, Bartoszewicz Z. Hiperprolaktynemia. Endokrynol Pol 1997; 48: 135-150.

10. Skałba P. Choroby podwzgórza i przysadki w aspekcie zaburzeń rozrodczości. Medipress Ginekol 1999; 5: 23-28.

11. Melmed S, Casanueva FF, Hoffman AR, et al. Diagnosis and treatment of hyperprolactinemia: an Endocrine Society clinical practice guideline. J Clin Endocrinol Metab 2011; 96: 273-288.

12. Casanueva FF, Molitch ME, Schlechte JA, et al. Guidelines of the Pituitary Society for the diagnosis and management of prolactinomas. Clin Endocrinol 2006; 65: 265-273.

13. Badowska-Kozakiewicz AM. Biologiczna rola prolaktyn. Przegl Menopauz 2012; 4: 305-308.

14. Pawlik-Sobecka L, Nawrot L, Kokot I. Hiperprolaktynemia - istotny problem w opiece farmaceutycznej, diagnostycznej i klinicznej. Diag Klin 2013; 69: 79-85

15. Tsuji K, Sowa M, Nakano R. Relationship among the status of the human oocyte, the 17 beta-estradiol concentration in the antral fluid and the follicular size. Endocrinol Jpn 1983; 30: 251-254.

16. Kauppila A, Leinonen P, Vihko R, Ylöstalo P. Metoclopramide-induced hyperprolactinemia impairs ovarian follicle maturation and corpus luteum function in women. J Clin Endocrinol Metab 1982; 54: 955-960.

17. Demura R., Ono M, Demura H, et al. Prolactin directly inhibits basal as well as gonadotropin-stimulated secretion of progesterone and 17 beta-estradiol in the human ovary. J Clin Endocrinol Metab 1982; 54: 1246-1250.

18. del Pozo E, Wyss $\mathrm{H}$, Tollis $\mathrm{G}$, et al. Prolactin and deficient luteal function. Ostet Genecol 1979; 53: 282-286.

19. Cutie E, Andino NA. Prolactin inhibits the steroidogenesis in midfollicular phase human granulosa cells cultured in a chemically defined medium. Fertil Steril 1988; 49: 632-637

20. McNatty KP. Relationship between plasma prolactin and the endocrine microenvironment of the developing human antral follicle. Fertil Steril 1979; 32: 433-438.

21. Bhasin S, Enzlin P, Coviello A, Basson R. Sexual dysfunction in men and women with endocrine disorders. Lancet 2007; 369: 597-617.

22. Jarząbek-Bielecka G, Nowaczyk A, Sowińska-Przepiera E, et al. Analiza stężeń prolaktyny $u$ dziewcząt bez cech endokrynopatii z zaburzeniami miesiączkowania i stresem w wywiadzie. Ginekol Prakt 2010; 1: 46-53.

23. Benker G, Jaspers C, Häusler G, Reinwein D. Control of prolactine secretion. Klin Wochenschr 1990; 68: 1157-1167.

24. Zgliczyński W, Zdunowski P. Hyperprolactinemia - pitfalls in PRL assessment. Pol J Endocrinol 2005; 6: 980-985.

25. Sadamatsu M, Kato $\mathrm{N}$, lida $\mathrm{H}$, et al. The 24 hour rhythms in plasma growth hormone, prolactin and thyroid stimulating hormone:effect of sleep deprivation. J Neuroendocrinol 1995; 7: 597-606.

26. Karasek M, Pawlikowski M, Lewiński A. Hyperprolactinemia: causes, diagnosis and treatment. Pol J Endocrinol 2006; 57: 656-662.

27. McCudden CR, Sharpless JL, Grenache DG. Comparison of multiple methods for identification of hyperprolactinemia in the presence of macroprolactin. Clin Chim Acta 2010; 411: 155-160 
28. Gibney J, Smith TP, McKenna TJ. Clinical relevance of macroprolactin. Clin Endocrinol 2005; 62: 633-643.

29. Jeske W. Przyczyny rozbieżności wyników oznaczeń prolaktyny i powody prawdziwej albo pozornej niezgodności ze stanem klinicznym. Pol J Endocrinol 2008; 59: 30-32.

30. Hattori N. Macroprolactinemia: a new cause of hyperprolactinemia J Pharmacol Sci 2003; 92: 171-177.

31. Ruchała M, Szczepanek-Parulska E. Objawy neurologiczne w najczęstszych chorobach endokrynologicznych. Med Dypl Endokrynol 2014: 69-78.

32. Dudkiewicz J, Grzonka D, Czarnecki M. Sposoby leczenia czynnościowej, jawnej hiperprolaktynemii u kobiet z niepłodnością. Gin Pol 1998; 69: 1171-1174.

33. Kaiser UB. Hyperprolactinemia and infertility: new insights. J. Clin Invest 2012; 122: 3467-3468.

34. Wołczyński S, Kuczyński W, Kurzawa R. Rekomendacje dotyczące diagnostyki i leczenia niepłodności - skrót. Ginekol Pol 2012; 83: 149-154.

35. Stanosz S, Zochowska E, Safranow K, et al. Influence of modified transdermal hormone replacement therapy on the concentrations of hormones, growth factors, and bone mineral density in women with osteopenia. Metabolism 2009; 58: 1-7.

36. Gomes RC, Maioral GC, Verna C, et al. Hyperprolactinemia changes the sulfated glycosaminoglycan amount on the murine uterus during the estrous cycle. Fertil Steril 2013; 100: 1419-1427.

37. Verhelst J. Abs R. Hyperprolactinemia: pathophysiology and management Treat Endocrinol 2003; 2: 23-32.

38. Colao A, di Sarno A, Pivonello R, et al. Dopamine receptor agonists for treating prolactinomas. Expert Opin Investig Drugs 2002; 11: 787-800.

39. Skałba P. Leczenie hormonalne. Medycyna Praktyczna, Kraków 2005; 6: 21-26.

40. Ricci G, Giolo E, Nucera G, et al. Pregnancy in hyperprolactinemic infertile women treated with vaginal bromocriptine: report of two cases and review of the literature. Gynecol Obstet Invest 2001; 51: 266-270.

41. Ginsburg J, Hardiman P, Thomas M. Vaginal bromocriptine - clinical ad biochemical effects. Gynecol Endocrinol 1992; 6: 119-26.

42. Crosignani PG. Current treatment issues in female hyperprolactinaemia Eur J Obstet Gynecol Reprod Biol 2006; 125: 152-164.

43. Serri O, Beauregard H, Lesage J, et al. Long term treatment with CV 205-502 in patients with prolactin-secreting pituitary microadenomas. J Clin Endocrinol Metab 1990; 71: 682-687.

44. Martin KA, Hall JE. Pulsatile GnRH in hypogonadism. w Ovulation Induction. Procc of the 2-nd World Conference on Ovulation Induction (Fillocori M, Flamigni C, eds.). Butler-Tanner Ltd. New York, London 1998: 47-54.

45. Ben-David M, Schenker JG. Transient hyperprolactinemia: a correable cause of idiopathic female infertility. J Clin Endocrinol Metab 1983; 57: 442-444.

46. Mancini T, Casanueva FF, Giustina A. Hyperprolactinemia and prolactinomas, Endocrinol Metab Clin North Am 2008; 37: 67-99.

47. Shimon I, Bronstein MD, Shapiro J, et al. Women with prolactinomas presented at the postmenopausal period. Endocrine 2014; 47: 889-894.

48. Gillam MP, Molitch ME, Lombardi G, Colao A. Advances in the treatment of prolactinomas. Endocrinol Rev 2006; 27: 485-534.

49. Fideleff HL, Boquete HR, Suárez MG, Azaretzky M. Prolctinoma in children and adolescents. Horm Res 2009; 72: 197-205.

50. Abu-Fadil S, DeVane G, Siler TM, Yen SS. Effects of oral contraceptive steroids on pituitary prolactin secretion. Contraception 1976; 13: 79-85.

51. Shibli-Rahhal A, Schelechte J. The effects of hyperprolactinemia on bone and fat. Pituitary 2009, 12: 96-104.

52. Doknic M, Pekic S, Zarkovic M, et al. Dopaminergic tone and obesity: an insight from prolactinomas treated with bromocriptine. Eur J Endocrinol 2002; 147: 77-84.

53. Wang GJ, Volkow ND, Logan J, et al. Brain dopamine and obesity. Lancet 2001; 357: 354-357.

54. Tuzcu A, Bahceci M, Dursun M, et al. Insulin sensitivity and hyperprolactinemia. J Endocrinol Invest 2013; 26: 341-346.

55. Seriwatanachai D, Krishnamra N, van Leeuwen JP. Evidence for direct effects of prolactin on human osteoblasts: Inhibition of cell growth and mineralization. J Cell Biochem 2009; 107: 677-685.

56. Seriwatanachai D, Thongchote K, Charoenphandhu N, et al. Prolactin directly enhances bone turnover by raising osteoblast-expressed receptor activator of nuclear factor kappaB ligand/osteoprotegerin ratio. Bone 2008; 42: 535-546.
57. Mazziotti G, Mancini T, Mormando M, et al. High prevalence of radiological vertebral fractures in women with prolactin-secreting pituitary adenomas. Pituitary 2011; 14: 299-306.

58. Stanosz M, Myśliwiec L, Stanosz S. Stężenie markerów tworzenia i resorpcji kości u kobiet ze zmianami zwyrodnieniowymi trzonów kręgów lędźwiowych we wczesnym okresie pomenopauzalnym. Ortop Traumatol Rehab Medsportpress 2006; 6: 608-612.

59. Schlechte JA, Scherman B, Martin B. Bone density in amenorrheic women with and without hyperprolactinemia. J Clin Endocrinol Metab 1983; 56: 1120-1123.

60. Kollin E, Gergely I, Szücs J, Holló I. Decreased bone density in hyperprolactinemic women. N Eng J Med 1981; 304: 1362-1363.

61. Klibanski A, Greenspan SL. Increase in bone mass after treatment of hyperprolactinemic amenorrhea. N Engl J Med 1986; 315: 542-546.

62. Schlechte J, el-Khoury G, Kathol M, Walkner L. Forearm and vertebral bone mineral in treated and untreated hyperprolactinemic amenorrhea. J Clin Endocrinol Metab 1987; 64: 1021-1026.

63. Karunakaran S, Page RCL, Wass JAH. The effect of the menopause on prolactin levels in patients with hyperprolactinaemia. Clin Endocrinol 2001; 3: 295-300.

64. dos Santos Nunes V, El Dib R, Boguszewski CL, Nogueria CR. Cabergoline versus bromocriptine in the treatment of hyperprolactinemia:a systematic review of randomized controlled trials and meta-analysis. Pituitary 2011; 14: 259-265.

65. Glazener CM, Sargood AJ, Jackson PC, et al. Osteoporosis and amenorrhea in young women. Gynecol Endocrinol 1987; 1: 255-261.

66. Inancli SS, Uluogullari A, Ustu Y, et al. Effect of cabergoline in insulin sensitivity, inflammation and carotid intima media thickness In patients with prolactinoma. Endocrine 2012; 44: 193-199.

67. Webster J, Piscitelli G, Polli A, et al. A comparison of cabergoline and bromocriptine in the treatment of hyperprolactinemic amenorrhea. Cabergoline comparative study group. N Engl J Med 1994; 331: 904-909.

68. Auriemma RS, Granieri L, Galdiero M, et al. Effect of carbogoline on metabolism in prolactinomas. Neuroendocrinology 2013; 98: 299-310.

69. Ciresi A, Amato MC, Guarnotta V, et al. Higher doses of cabergoline further improve metabolic parameters in patients with prolactinoma regardless of the degree of reproduction in prolactin levels. Clin Endocrinol 2013; 79: 845-852

70. Inancli SS, Usluogullari A, Ustu Y, et al. Effect of cabergoline on insulin sensitivity, inflammation, and carotid intima media thickness in patients with prolactinoma. Endocrine 2012; 44: 193-199.

71. Iacovazzo D, De Marinis L. Treatment of hyperprolactinemia in post-menopausal women: pros. Endocrine 2015; 48: 76-78. 